\title{
A multicentre investigation of organ and tissue donation education for critical care residents
}

\section{Enquête multicentrique sur l'éducation des résidents en soins intensifs sur les dons d'organes et de tissus}

\author{
Aimee J. Sarti, MD · Stephanie Sutherland, PhD • Andrew Healey, MD • Sonny Dhanani, MD • \\ Michael Hartwick, MD · Simon Oczkowski, MD • David Messenger, MD • Karim Soliman, MD • \\ Ian Ball, MD • Briseida Mema, MD • Mikhail-Paul Cardinal • Sabira Valiani, MD • \\ Pierre Cardinal, MD
}

Received: 21 November 2017/Revised: 9 March 2018/Accepted: 11 April 2018/Published online: 26 June 2018

(C) Canadian Anesthesiologists' Society 2018

\begin{abstract}
Purpose To describe critical care medicine residents' training, expertise, and skills regarding organ and tissue donation processes and procedures.

Methods We undertook a qualitative multicentre study and employed a purposive sample of program directors, physicians, nurses, residents, and organ donation leaders from all nine academic intensive care unit (ICU) training centres (five adult, four pediatric) in Ontario $(n=71)$. Interviews, conducted by telephone between December 2015 and March 2016, were audio-recorded and transcribed verbatim. Data collection and analysis were performed using an iterative process and continued until saturation was achieved.

Results Five main themes were identified: 1) gaps in residents' knowledge for both neurologic determination of death (NDD) and circulatory determination of death
\end{abstract}

A. J. Sarti, MD $(\bowtie) \cdot$ S. Sutherland, PhD · M. Hartwick, MD . M.-P. Cardinal · P. Cardinal, MD

Department of Critical Care, Ottawa Hospital, Ottawa, ON,

Canada

e-mail: asarti@toh.ca

A. Healey, MD

Division of Emergency Medicine, Department of Medicine,

McMaster University, Hamilton, ON, Canada

S. Dhanani, MD

Department of Pediatrics, University of Ottawa, Children's

Hospital of Eastern Ontario (CHEO), Ottawa, ON, Canada

S. Oczkowski, MD

Division of Critical Care, Department of Medicine, McMaster

University, Hamilton, ON, Canada
(DCD) cases; 2) commitment to the provision of organ and tissue donation training; 3) limited experiential learning (NDD and DCD); 4) challenges related to the provision of training on organ donation and need for a standardized curriculum; and 5) communication with family members. Overall, this study showed system-level gaps in training resulting from the lack of a standardized provincial curriculum on organ donation.

Conclusions Qualitative data corroborated that residents need more exposure to clinical cases, especially regarding DCD donors. A standardized education curriculum would be beneficial for all residents within the ICU. Developing a better shared understanding of the donation process will improve team communication and performance, translate into a better end-of-life experience for families, and potentially result in increased donation rates.

D. Messenger, MD

Department of Emergency Medicine and Critical Care Medicine,

Queen's University, Kingston, ON, Canada

K. Soliman, MD

Department of Critical Care, Queen's University, Kingston, ON, Canada

I. Ball, MD

Department of Medicine and Department of Epidemiology and Biostatistics, Western University, London, ON, Canada

B. Mema, MD

Department of Critical Care, The Hospital for Sick Kids,

Toronto, ON, Canada

S. Valiani, MD

Saskatoon Health Region, Saskatoon, SK, Canada 


\section{Résumé}

Objectif Décrire la formation, l'expertise et les habiletés des résidents en soins intensifs concernant les processus et procédures de don d'organes et de tissus.

Méthodes Nous avons entrepris une étude qualitative multicentrique et avons utilisé un échantillonnage raisonné de directeurs de programmes, médecins, infirmières, résidents et spécialistes des dons d'organes dans les neuf unités de soins intensifs (USI) universitaires (cinq adultes, quatre pédiatriques) en Ontario $(n=71)$. Les entretiens téléphoniques ont eu lieu entre décembre 2015 et mars 2016; ils ont été enregistrés et ont été retranscrits mot pour mot. La collecte et l'analyse des données a été effectuée en utilisant un processus itératif et a été poursuivie jusqu'à saturation.

Résultats Cinq thèmes principaux ont été identifiés : 1) chez les résidents, des lacunes de connaissances, à la fois, sur des cas de détermination neurologique de la mort (NDD) et des cas de détermination vasculaire de la mort $(D C D)$; 2) un engagement envers la délivrance d'une formation sur le don d'organes et de tissus; 3) un apprentissage expérientiel limité (NDD et DCD); 4) les difficultés liées à la délivrance d'une formation sur le don d'organes et de tissus et le besoin d'un programme d'études standardisé; et 5) la communication avec les membres de la famille. Globalement, l'étude a fait apparaître les lacunes de formation au niveau du système découlant d'une absence de programme d'études standardisé au niveau provincial sur le don d'organes.

Conclusions Les données qualitatives ont corroboré le sentiment que les résidents devaient être davantage exposés à des cas cliniques, en particulier concernant les donneurs en arrêt cardio-circulatoire. Un programme de formation standardisé à l'attention de tous les résidents en USI serait bénéfique. Le développement d'une meilleure compréhension partagée du processus de don améliorera la communication au sein de l'équipe et ses performances, se traduira en une meilleure expérience de fin de vie pour les familles et pourrait entraîner une augmentation du taux de dons.

The need for transplantable organs is rapidly increasing worldwide largely because of advances in transplantation science. ${ }^{1}$ Improved operative/perioperative transplant care and immunosuppressive management have led to the use of more liberal transplantation criteria for patients with, for example, heart, lung, or liver failure. ${ }^{2}$ Despite improvement of the organ donation process, the number of organs available for transplantation has not increased at a sufficient pace to meet the ever-increasing demand.

Organ donation and transplantation rates have increased in Canada with 18.2 donors per million in 2016. ${ }^{3}$ Nevertheless, despite a $>30 \%$ increase in the number of organs available for transplantation between 2010 and 2014 , the number of patients awaiting transplantation, as well as the number of patients who died while awaiting transplantation, increased by $21 \%$ and $27 \%$, respectively, over the same period. ${ }^{4}$ In an attempt to further increase donor rates, the Trillium Gift of Life Network (TGLN) of Ontario (an organ donation organization) decided to intensify its educational efforts. ${ }^{5}$ Many studies have shown that training not only improves knowledge but also changes the attitudes of healthcare professionals towards organ donation and increases organ donation rates. $^{6-9}$

Critical Care Medicine physicians play an important role in the identification, recruitment, and care of potential organ donors and of transplant recipients. Only one published study has examined critical care residents' knowledge of organ donation. ${ }^{10}$ Gupta et al. conducted a cross-sectional survey of 40 residents rotating through the intensive care units (ICUs) at Johns Hopkins Hospital (USA), 17 of whom were critical care residents. The average knowledge score regarding solid organ transplantation and the donor process was $50 \%$ in all participants with no detectable difference between the median knowledge score of critical care residents and other rotating residents. ${ }^{10}$

In concert with the Royal College of Physicians and Surgeons of Canada, TGLN conducted a needs assessment (NA) to help implement an educational program targeting critical care residents. The NA was designed to describe critical care medicine residents' training, expertise, and skills regarding organ and tissue donation processes and procedures.

\section{Methods}

This study received ethics approval from institutional review boards at all nine academic sites. With funding from TGLN, we conducted a qualitative multicentre study involving all Critical Care Medicine training programs in Ontario, Canada (five adult, four pediatric). Qualitative data collection and analysis were performed using an iterative process and continued until saturation was achieved. In qualitative studies, data saturation occurs when the researchers no longer obtain new information/ themes. ${ }^{11}$ 
Data collection

Interview protocols were created, iteratively reviewed, and revised by an interdisciplinary team of investigators with expertise in organ donation, medical education, sociology, and qualitative research methods. All interview protocols were designed to follow a semi-structured, broad, predetermined line of inquiry that was flexible and could evolve as data collection unfolded, permitting exploration of emerging themes. ${ }^{11}$ In addition, closed-ended questions were asked regarding residents' experience and knowledge.

Interviews, conducted by telephone between December 2015 and October 2016, were audio-recorded and transcribed verbatim. Team members who conducted the interviews all have extensive experience and expertise in qualitative interviewing. Two of the interviewers were clinicians (ICU physicians and ICU registered nurse); the third interviewer was a $\mathrm{PhD}$ with ten years of experience in medical education. Interview participants included program directors (PDs) from every critical care program as well as critical care residents (Res), nurses, intensivists, and TGLN leaders (see Table). Residents in their final year of training were identified by their respective PD targeting an enrolment of two to three per site. Intensivists and nurses were identified in collaboration with TGLN leaders via purposive and snowball sampling with the goal of providing a balanced representation of the collective group, targeting enrolment of two intensivists and two nurses from each site.

Data analysis

Qualitative data analysis employed inductive coding techniques. Themes were generated directly from the raw data. The analysis team consisted of three researchers who all participated in coding training and meetings to develop the codebook. There was ongoing group discussion and agreement on emergence of new themes. ${ }^{11}$ Interviews were coded and entered into Nvivo software (QRS International, Melbourne, Australia). Closed-ended questions were also included, which allowed for calculation of proportions.

\section{Study rigour}

Multiple strategies were employed to minimize threats to the validity/credibility of the study. Efforts were made to search for disconfirming evidence using purposive sampling, with the selection of participants to provide a balanced representation of the collective group, including potential differences of opinion. Two forms of triangulation were employed to achieve a balanced perspective and enhance the reliability of the conclusions: 1) data source triangulation (using multiple data sources and informants) and 2) investigator triangulation (using more than one person to collect, analyze, and interpret data).

\section{Results}

A total of 71 participants representing all nine academic training centres in Ontario participated in the interviews (see Table).

Five main themes were identified: 1) gaps in residents' knowledge; 2) commitment to the provision of organ and tissue donation training; 3) limited experiential learning; 4) challenges related to the provision of training on organ donation and need for a standardized curriculum; and 5) communication with family members.

\section{Gaps in residents' knowledge}

During the interviews, residents were asked a series of questions to explore their knowledge and skills pertaining to donor criteria and the organ donation processes for both donors after the neurologic determination of death (NDD)

Table Study participants

\begin{tabular}{|c|c|c|c|c|c|}
\hline Critical Care Training Program & Program Director & MD & Nurse & Resident & TGLN Leaders \\
\hline Toronto - Adult & 1 & 2 & 2 & 3 & \\
\hline Toronto - Pediatric & 1 & 1 & 2 & 1 & \\
\hline Ottawa - Adult & 1 & 2 & 2 & 2 & \\
\hline Ottawa - Pediatric & 1 & 2 & 2 & 1 & \\
\hline London - Adult & 1 & 2 & 2 & 0 & \\
\hline London - Pediatric & 1 & 2 & 2 & 1 & \\
\hline Hamilton - Adult & 1 & 2 & 2 & 3 & \\
\hline Hamilton - Pediatric & 1 & 2 & 2 & 2 & \\
\hline Kingston - Adult & 1 & 2 & 2 & 3 & \\
\hline Total & 9 & 17 & 18 & 16 & 11 \\
\hline
\end{tabular}

MD = medical doctor; TGLN $=$ Trillium Gift of Life Network 
and circulatory determination of death (DCD). Approximately $25 \%$ of residents provided incorrect answers pertaining to donor referral criteria, stating that they would not refer patients with human immunodeficiency virus, history of cancer, or age $>85$ yr. This represents gaps in both the knowledge and understanding of best practice.

The majority of residents understood the fundamental elements included in a declaration of neurologic death. Nevertheless, detailed knowledge about specific aspects of the declaration was poorly understood. For example, only $50 \%$ of residents correctly described the ocular response to a cold caloric test (oculo-vestibular reflex), "no movement of the eyes". The other $50 \%$ of residents did not answer, provided the wrong answer, or were not confident in their answer.

So, either no response at all, which in my limited experience has been the most common. And to be honest, I would have to look up what kind of response is acceptable. (Res)

And,

The eyes go towards the same side but I always have to double check that one...(Res)

The majority of participants understood the possible confounders of brain death. Nevertheless, the purpose and names of ancillary testing were not as well understood.

You have to look at the cerebral blood flow. Nuclear medicine has traditionally been the standard, but I think $C T$ and even MR angiography have similar specificity...sorry, similar sensitivity but not as specific...sorry, the other way around. (Res)

Knowledge surrounding DCD was not as accurate as with NDD. The majority of residents were uncertain about how DCD could affect the timing and/or location of withdrawal of life-sustaining therapy. Only $25 \%$ of residents correctly described the complete procedure used to declare death by circulatory criteria for the purpose of organ donation. When asked how they would declare death for a potential DCD donor, many were uncertain:

This is something...I'm just maybe not familiar enough with. I don't think there is a standard declaration for circulatory death specific to DCD. I think you would declare as any provider would. (Res)

And,

I don't know, I can't really answer that. I've never been in the operating room when it happened. I think...I would imagine it's just the same in regular clinical practice the person is cardiovascularly dead. (Res)

Commitment to the provision of training on organ and tissue donation

Program directors were all strongly committed to the provision of training on organ and tissue donation education. All programs provided one to two academic half days or lectures along with bedside teaching. In addition, some programs offered a simulated patient encounter surrounding communication and one program offered an organ and tissue donation elective.

I think it [organ and donation competency curriculum] should be mandatory, and by mandatory, I'd say someone needs to complete four modules per year. (PD)

Intensivists also expressed the importance of learning about organ and tissue donation as part of residents' training.

Absolutely, residents need more education with regard to organ donation, particularly with the practice of declaration and ancillary testing. (Physician)

Limited experiential learning

The importance of experiential learning was highlighted by all participants. Also, it was noted that different residents have different needs, some requiring more clinical exposure to become competent. Nevertheless, the number of clinical encounters was judged to be insufficient.

I don't think critical care trainees get enough exposure, it is more of a lifelong experience. Certainly, I don't think any fellowship develops enough exposure if you don't have enough volume. And, we certainly have a high volume so if we have a problem, I would hate to think of what other places have. (Physician)

Data showed that the experience for residents in ICUs across Ontario is limited, especially for DCD. Ninety-four percent of residents had observed an intensivist managing a NDD donor case, and $76 \%$ reported having been observed managing a NDD donor case. Forty-seven percent of residents reported having been the second physician performing the NDD death declaration. In contrast, 35\% had observed a DCD donor case and 6\% had been observed. Only $18 \%$ reported having been the second physician performing the death declaration during a DCD donation case.

The biggest gap [in fellowship training] is how frequently trainees see DCD, and so it's entirely possible that they would not see it at all depending on whether there are donors in the unit. So, it is possible they are missing out on declarations. (Physician)

Participants noted that the quality of teaching, in the few instances when residents are called upon to manage potential donors, could also vary widely given that not all ICU attendings have a special interest in organ donation.

It should be at the bedside, and I think that then means that whoever the expert is going to be or whoever the intensivist is, because whether you like it or not, you're not 
always going to have "an expert" but you are going to have an intensivist there all the time. (PD)

Nevertheless, participants acknowledged the contribution of organ and tissue donation coordinators (OTDC) who often provided bedside teaching.

The interactions with the Trillium staff have always been great interactions. They are mostly at the bedside of patients who are potential candidates or potentially being worked up for determination of neurologic death. Most of the time I would say they are in the room when we do declare brain death and they're always more than willing to answer any questions. (Res)

Challenges related to the provision of training on organ donation and need for a standardized curriculum

Despite PDs all reporting offering formal teaching sessions specifically focused on organ and tissue donation, only $53 \%$ of residents interviewed had attended such a session during their critical care residency. None of the residents had participated in a simulated encounter related to organ and tissue donation and only $18 \%$ indicated ever having been formally assessed. Both TGLN leaders and PD described how the organ donation curriculum, which is locally developed and implemented, is not standardized across academic teaching sites potentially leading to variability in both the content and quality of educational interventions.

One of the things I find extremely frustrating is that we are all in different parts of the country and we are all trying to reinvent the wheel a lot of the time. I am absolutely a big fan of standardizing specific parts of the fellowship because we all have to do it, right? For certain core competencies I do think that national organizations should play a better role than they do in core competency assessment and program delivery. (PD)

Communication with substitute decision makers/family members

Regarding communication, three interrelated sub-themes emerged including: roles and responsibilities to initiate and discuss organ donation, missed educational opportunities, and comfort discussing organ and tissue donation.

Roles and responsibility to initiate and discuss organ donation

Residents interpreted their roles and responsibilities regarding family meetings on donation in different ways. Some residents understood that they had little, if any, role to play in any family discussion surrounding organ donation and were agreeable to delegate all responsibilities to the organ and tissue donation coordinator.

I think if the patient is going in that direction it is nice having Trillium already involved and sort of knowing what the family's wishes are. I usually don't bring that up myself in terms of the possibility for donation. But, I think Trillium's probably better equipped at approaching that with the family, you know, in a better way than maybe I could. (Res)

In contrast, other residents felt that communication around donation was mainly the responsibility of the staff intensivist, indicating that it was their staff and themselves who initiated such conversations.

Interviewer: Who, at your hospital, who is primarily responsible for having the discussions about organ donation with the family?

Respondent: It's the physician, the staff.

And,

When we reach the point of organ donation, it is initiated by the physician staff, but then it's also continued by Trillium. (Res)

Finally, a few residents felt strongly that it was their responsibility (as opposed to the OTDC) to discuss donation with families because of an established relationship.

I am not comfortable not discussing it if it's a question addressed to me. So, I think a lot of times we tend to develop a rapport with the family and they trust us. (Res)

Residents were also asked to describe their role in family meetings held before the declaration of neurologic death. The purpose of this meeting is to inform the family of the patient's poor prognosis and the possibility of neurologic death. Nevertheless, the possibility of donation should not be introduced, in order to provide families time to process information and to decouple discussions pertaining to patient care from those pertaining to donation. ${ }^{12}$ Twenty-five percent of residents mentioned that they would introduce the possibility of organ donation before the actual declaration of neurologic death.

\section{Missed educational opportunities}

Some residents felt that they were missing opportunities by not being the primary contact for families in discussing organ and tissue donation.

I think it is potentially missing an opportunity by not training us to be more familiar and be able to successfully convey the appropriate message and information while at the same time, building on a therapeutic alliance that we've already established with the patients and families. I think that if it ultimately leads to more successful donations, then I'm okay with taking a back seat. But if 
it's sort of a matter of needing extra training, then there might be more benefit in us participating. (Res)

Similarly, some healthcare providers and PDs expressed concern that residents do not receive education/training in communicating with families regarding organ donation, highlighting instances where they may require these skills (i.e., if the OTDC is not available or if they practice in a province with a different system).

My discomfort with the idea that we don't teach our residents "the ask" about organ donation because ideally a coordinator would do it. Well, I think that is true, practically speaking but there isn't always a coordinator that is available. I mean, we are told in theory, that they can be dispatched in the middle of the night but I've certainly had circumstances where a family was going to withdraw right then and there and the opportunity for "the ask" was going to be gone in about $30 \mathrm{sec}$, and I do feel in that scenario it's a missed opportunity for the patient and for the family that they are not given that information. (PD)

\section{Discomfort discussing organ and tissue donation} with substitute decision-makers (SDMs)

Residents stated they were uncomfortable discussing organ and tissue donation with SDMs.

Interviewer: And how comfortable are you with not discussing organ donation with the family?

Respondent: Actually, I think it's the opposite. This is something I'm not comfortable with. But if I was ever in the community and, as I understand it, they will always be available by phone and they will always be the people broaching it by phone, but, having training at an academic centre and having only really worked in an academic centre, I lack comfort in broaching all of that without the coordinators. (Res)

Similarly, other residents didn't expressly state their discomfort in discussing donation with families yet they described how they were content with relying on the OTDC's expertise to take full responsibility for all aspects of organ donation communication with families.

I mean I think if they bring it up to me, I don't shut it down. I don't say we're not allowed to talk about this. I kind of have a general spiel, for example, "it's touching that you're thinking of that right now during this time and it's certainly something to discuss amongst your family about whether you want this for your family member or your family member would want to have. And we actually have someone with the Trillium Life Network who has a lot of information and would love to speak to you about this." And so I typically kind of prep them that our coordinator is going to be coming in to talk with them. And that's kind of where I leave it. I try not to get into specifics and I don't often bring it up myself. (Res)
Programs hope for more education centred on communication with families using different modalities (such as simulation) given that there are few opportunities for physicians to discuss donation with families:

I think it is important to have simulations around how you have conversations with families, how you approach the subject of organ donation, particularly in the clinical context now where actually trainees and medical staff are actively discouraged from talking to families about organ donation at Trillium's behest. (PD)

\section{Discussion}

We conducted a qualitative multicentre study within the nine critical care academic training centres in Ontario. This study showed system-level gaps in training resulting from the lack of a standardized provincial curriculum on organ donation. Program directors uniformly espoused the importance of organ and tissue donation; however, many critical care residents in their last year of training reported having never attended a half-day session on organ donation and the greater majority of residents reported never having been formally assessed on organ donation. Challenges in the development and delivery of educational interventions and assessments were further compounded by the scarcity of clinical exposure to organ donation patients, particularly DCD. Not surprisingly, gaps in knowledge and skills were identified in different areas: the recognition of potential organ donors; the organ donation process for both NDD and DCD patients; and, in particular, the communication with families.

The knowledge gaps that we observed are worrisome, in particular given that the critical care residents interviewed were in their final year of training. Similar gaps have been previously observed for medical students, residents, ${ }^{6,10,13}$ and practicing physicians in other jurisdictions including the US, Italy, and Germany, suggesting little growth through medical training. ${ }^{14,15}$ Our results are comparable to those of Gupta et al., the only other study that included critical care trainees (17 critical care residents out of 40 residents in total). ${ }^{10}$ In their study, Gupta reported that only half of participants had previously facilitated deceased donor donation and reported an average knowledge score of $50 \% .^{10}$

As specialty programs address the challenges of implementing residency training under the new competency-based approach, innovative, multi-modal methods to both train and assess residents are required. To be valid, multiple assessments conducted by multiple trained assessors are required. ${ }^{16-18}$ In day-to-day clinical practice implementing competency-based education is challenging; however, it becomes even more complex for 
rare situations such as potential organ and tissue donation cases. Program directors, intensivists, and TGLN leaders all emphasized the need for a standardized curriculum and the provision of assessment instruments that could be shared amongst the different programs. They also emphasized that different means of simulation (e.g., virtual, theatre-based, and patient-actor) would no doubt be required to properly train and assess residents, noting that collaboration with provincial and national organ donation agencies would likely be necessary. ${ }^{19}$ In addition, participants mentioned that achieving proficiency in organ donation is likely a lifelong process given the limited clinical exposure; thus recognizing that competence is a matter of degree that cannot be easily examined using a binary yes/no model model. ${ }^{20}$ Reassuringly, the qualitative approach used to assess knowledge not only identified significant knowledge gaps but also that residents were very much aware of these gaps, stating that they would have to seek additional information especially for high-stake decisions (e.g., the declaration of death). Given the knowledge decay inherent to any educational activity, it is likely that decision-making in organ donation should also be supported by tools that provide timely, updated information adapted to the reality of each province. ${ }^{18}$

Most residents stated that they were not comfortable discussing organ donation with families and many were unaware of the importance of decoupling discussions about prognosis from discussions on donation. $^{21,22}$ Residents were also unclear as to their roles and responsibilities regarding family discussion on organ donation. Some residents believed that they had absolutely no role to play during family meetings pertaining to organ donation relegating all responsibilities to the OTDC, while others believed that critical care physicians were or should be primarily responsible for all organ donation discussions. Furthermore, both residents and healthcare professionals perceived that the lack of participation by residents during family meetings represented missed educational opportunities.

To our knowledge, this study is the first to describe residents' confusion regarding their roles and responsibilities in the organ donation process. Residents seem to adopt extreme positions by either relegating all responsibilities to the OTDC or deciding to approach families without involving the organ procurement organization. Either position can have deleterious effects regarding patient and family care, donation rates, and resident education. Relegating all responsibilities to staff from the OTDC may lead to a disengagement from patient and family care and become a disincentive to learning. Clinical environments that grant learners more clinical responsibilities add considerable motivation for learning, which in turn improves learning, academic performance, and the intention to continue to study. ${ }^{23,24}$ Conversely, assuming that physicians are or should be primarily responsible for all family discussions may lead to resentment and reluctance to embrace the contribution of other team members in particular the OTDC. ${ }^{25}$ Assigning the responsibility of obtaining consent to professionals who have received special training (e.g., the OTDC) is well supported in the literature. ${ }^{22,26-28}$ Nevertheless, it may also be beneficial to similarly train critical care residents, albeit not to the same extent as OTDCs, if only to help them understand the roles other team members play. ${ }^{29}$ Gaining a greater shared understanding of the tasks, roles, and responsibilities of other team members may also help coordinate relationships. ${ }^{30}$

Our study extends our understanding of resident knowledge deficits and the system challenges inherent in addressing them. Non-transplant physicians play a pivotal role in assisting patients and families with the decision to donate. Given that the residents we interviewed will soon become staff physicians, it is imperative that they have the competence and confidence to manage donation-related processes in practice. There are several limitations to our study. It was a cross-sectional study obtaining resident perceptions and knowledge at one point in time. The purposive sampling may result in a selection bias. All academic ICU training centres in Ontario participated in our study, but it is unclear whether we can generalize our findings to the broader national population. Future national-level mixed-method studies will need to be undertaken to determine if our findings are consistent and generalizable across Canada.

\section{Conclusion}

In summary, our study has identified significant gaps in knowledge for critical care residents in their last year of training. These gaps are not only caused by difficulties in developing and implementing an organ donation curriculum, but also due to the scarcity of organ donation. Participants emphasized the need for innovative means to assess residents as Critical Care Medicine training becomes competency-based. In addition, residents do not understand their roles and responsibilities and those of other healthcare professionals within the organ donation process. Some distance themselves from the donation process and others either become resentful of their perceived roles or take on additional responsibilities without any prior and necessary training. This can potentially negatively influence the donation process for families and markedly affect the outcome of the opportunity. Future educational 
interventions should address not only the medical aspects of organ donation (e.g., donor selection, care of the donor, declaration of death) but also ensure that residents understand the roles and responsibilities of all team members and how their role may need to change depending on the situation (e.g., OTDC not immediately available). We believe that developing a better shared understanding of the donation process will improve team communication and performance and translate into a better end-of-life experience for families potentially resulting in increased donation rates. Finally, this initial NA was important so as to leverage our broad understanding of Ontario to assist in informing subsequent NAs in other provinces prior to developing and implementing a national curriculum.

Acknowledgements $\mathrm{We}$ are grateful for the participation of healthcare professionals who participated representing all nine academic training centres in Ontario. This work was supported by the Trillium Gift of Life Network (TGLN) and the Royal College of Physicians and Surgeons of Canada (RCPSC).

Competing interests The authors have no competing interests.

Editorial responsibility This submission was handled by Dr. Sangeeta Mehta, Associate Editor, Canadian Journal of Anesthesia.

Author contributions Aimee J. Sarti, Stephanie Sutherland, and Pierre Cardinal contributed to the study conceptualization. Aimee J. Sarti, Stephanie Sutherland, Michael Hartwick, and Pierre Cardinal were involved in protocol development. Aimee J. Sarti, Stephanie Sutherland, Andrew Healey, Simon Oczkowski, David Messenger, Karim Soliman, Ian Bell, and Briseida Mema contributed to data collection. Aimee J. Sarti, Stephanie Sutherland, and Mikhail-Paul Cardinal were involved in data qualitative analysis. Aimee J. Sarti, Stephanie Sutherland, Mikhail-Paul Cardinal, and Pierre Cardinal were involved in manuscript preparation. Aimee J. Sarti, Stephanie Sutherland, Pierre Cardinal, Andrew Healey, Sonny Dhanani, Michael Hartwick, Simon Oczkowski, David Messenger, Karim Soliman, Briseida Mema, and Sabira Valiani contributed to critical review of the manuscript.

\section{References}

1. Matesanz R, Dominguez-Gill B, Coll E, de la Rosa G, Marazuela $R$. Spanish experience as a leading country: what measures were taken? Transpl Int 2011; 24: 333-43.

2. Mancini D, Lietz K. Selection of cardiac transplantation candidates in 2010. Circulation 2010; 122: 173-83.

3. Canadian Blood Services. Organ Donation and Transplantation in Canada: System progress report 2006-2015. 2016. Ottawa, ON. Available from URL: https://blood.ca/sites/default/files/ODT_ Report.pdf (accessed April 2018).

4. Canadian Institute for Health Information. eStatistics on Organ Transplants, Waiting Lists and Donors - 2016. Available from URL: https://blood.ca/sites/default/files/ODT_Report.pdf (accessed April 2018).

5. Trillium Gift of Life Network. Organ and Tissue Donation Saves Lives. Available from URL: https://www.giftoflife.on.ca/ (accessed April 2018).
6. Schaeffner E, Windisch $W$, Freidel $K$, Breitenfeldt $K$, Winkelmaver $W C$. Knowledge and attitude regarding organ donation among medical students and physicians. Transplantation 2004; 77: 1714-8.

7. Figueroa CA, Mesfum ET, Acton NT, Kunst AE. Medical students' knowledge and attitudes toward organ donation: results of a Dutch survey. Transplant Proc 2013; 45: 2093-7.

8. Murakami M, Fukuma S, Ikezoe M, et al. Effect of an educational program on attitudes towards deceased organ donation. Ann Transplant 2015; 20: 269-78.

9. Riker RR, White $B W$. The effect of physician education on the rates of donation requests and tissue donation. Transplantation 1995; 59: 880-4.

10. Gupta N, Garonzik-Wang J, Passarella R, et al. Assessment of resident and fellow knowledge of the organ donor referral process. Clin Transplant 2014; 28: 443-9.

11. Creswell JW. Educational Research: Planning, Conducting, and Evaluating Quantitative and Qualitative Research. Boston, MA: Pearson; 2012 .

12. Shemie SD, Robertson A, Beitel J, et al. End-of-life conversations with families of potential donors: leading practices in offering the opportunity for organ donation. Transplantation 2017; 101(5S Suppl 1): S17-26.

13. Bedi KK, Hakeem AR, Dave R, Lewington A, Sanfey H, Ahmad N. Survey of knowledge, perception, and attitude of medical students at the University of Leeds toward organ donation and transplantation. Transplant Proc 2015; 47: 247-60.

14. Pugliese MR, Degli-Esposti D, Venturoli $N$, et al. Hospital attitude survey of organ donation in the Emilia-Romagna region. Italy. Transpl Int 2001; 14: 411-9.

15. Youngner SJ, Landefeld S, Coulten CJ, Juknialis BW, Leary M. Brain death' and organ retrieval. A cross-sectional survey of knowledge and concepts among health care professionals. JAMA 1989; 261: 2205-10.

16. Stodel EJ, Wyand A, Crooks S, Moffet S, Chiu M, Hudson CC. Designing and implementing a competency-based training program for anesthesiology residents at the University of Ottawa. Anesthesiol Res Pract 2015; DOI: https://doi.org/10. 1155/2015/713038.

17. Caraccio $C$, Englander $R$, Van Melle E, et al. Advancing competency-based medical education: a charter for clinician educators. Acad Med 2016; 91: 645-9.

18. Lockyer J, Carraccio C, Chan MK, et al. Core principles of assessment in competency-based medical education. Medical Teacher 2017; 39: 609-16.

19. Aggarwal R, Mytton OT, Derbrew $M$, et al. Training and simulation for patient safety. Qual Saf Health Care 2010; 19(Suppl 2): i34-43.

20. Talbot $M$. Monkey see, monkey do: a critique of the competency model in graduate medical education. Med Educ 2004; 38: 587 92.

21. DeJong W, Franz $H G$, Wolfe SM, et al. Requesting organ donation: an interview study of donor and nondonor families. Am J Crit Care 1998; 7: 13-23.

22. Gortmaker $S$, Beaskey $C$, Sheehy $E$, et al. Improving the request process to increase family consent for organ donation. J Transplant Coord 1998; 8: 210-7.

23. Contillon P, Macdermott M. Does responsibility drive learning? Lessons from intern rotations in general practice. Med Teach 2008; 30: 254-9.

24. Kusurkar R, Ten Cate TJ, Van Asperen M, Croiset G. Motivation as an independent and dependent variable in medical education: a review of the literature. Med Teach 2011; 33: e242-62.

25. Williams MA, Lipsett PA, Rushton $\mathrm{CH}$, et al. The physician's role in discussing organ donation with families. Crit Care Med 2003; 31: 1568-73. 
26. Klieger J, Nelson K, Davis $R$, et al. Analysis of factors influencing organ donation consent rates. J Transplant Coord 1994; 4: 132-4.

27. Siminoff LA, Gordon N, Hewlett J, Arnold RM. Factors influencing families' consent for donation of solid organs for transplantation. JAMA 2001; 286: 71-7.

28. Siminoff LA, Molisani A, Traino HM. A comparison of the request process and outcomes in adult and pediatric organ donation. Pediatrics 2015; 136: e108-14.
29. Cannon-Bowers JA, Salas E, Blickensderfer E, Bowers CA. The impact of cross-training and workload on team functioning: a replication and extension of initial findings. Human Factors 1998; 40: 92-101.

30. Cardinal $P$, Christian $M D$, Jeffers $N$, Brindley $P G$. Task management in acute care medicine. In: Brindley PG, Cardinal $P$ (Eds). Optimizing Crisis Resource Management to Improve Patient Safety and Team Performance. Royal College of Physicians and Surgeons of Canada; 2017: 35-46. 